\title{
FORMÁLÓDÓ ÚJ EURÓPAI NÖVEKEDÉSI KÖZPONTOK? A KÖZÉP-EURÓPAI TÉRSÉG METROPOLISZRÉGIÓINAK SAJÁTOSSÁGAI ÉS KIHÍVÁSAI
}

\author{
(Formulating New European Growth Poles? Special Features \\ and Challenges of the Central European Metropolregions)
}

\section{SCHNEIDER GÁBOR}

Kulcsszavak:

regionális versenyképesség növekedési központok metropoliszrégió többszintủ kormányzás funkcionális makrorégió

A tanulmány az európai növekedési központok erösödỏ gazdasági szerepe és egyedi sajátosságai felöl mutatja be a közép-európai térség metropoliszrégióit. A regionális versenyképesség vizsgálatában a szerzö ässzekapcsolja a területi adotsságokat a társadalmi, az igazgatási és irányítási szerepkörrel. Az uniós rendszerezés alapján jellemzi a közép-európai (fövárosi) növekedési központokat, rámutatva azok fejlettségi szintjére, illetve elmaradásaira.

E tanulmány az európai növekedési központok ${ }^{1}$ erősödő gazdasági szerepét és egyedi sajátosságait mutatja be kiemelten a területi adottságokra, a társadalmi, az igazgatási és irányítási szerepkörükre fókuszálva². E régiók ugyanis az európai regionális versenyképesség elsó számú területi szereplöi és letéteményesei. Az egyedi speciális sajátosságaik mellett fontos nemzetközi hálózatteremtési képességük kiemelése is, amellyel e régiók a transz- és interregionális, valamint a határ menti együttmüködések legfontosabb mozgatói.

A globális pénzügyi és gazdasági válság nyomán bebizonyosodott, hogy a legtöbb közép-európai régió különösen sérülékeny, melyet a Régiók 2020 uniós jelentés és a Barca-jelentés is egyaránt kiemeltek (Európai Bizottság 2008a; 2009a). A jelentések egymástól függetlenül megállapították, hogy leginkább sebezhetóek a déleurópai térség, valamint az újonnan csatlakozott tagállamok régiói ${ }^{3}$. Komoly viszszaesés következett be az ipari termelést végző régióknál, de a szolgáltatás-orientált régiók esetében is, például a pénzügyi szektorban (Európai Bizottság 2009b). $\mathrm{Az}$ OECD elemzése és az Európai Bizottság Hatodik elörehaladásí jelentése pedig arra hívták fel figyelmünket, hogy azok a régiók lábalhatnak ki a válságból a legsikeresebben, amelyek helyi sajátosságokon alapuló, magas technológia-orientált fejlesztéseket alkalmaznak (Európai Bizottság 2009c; OECD 2009).

Közép-Európában a növekedési központok szerepét a fövárosi régiók látják el, amelyek fejlettségük alapján kiemelkednek országuk többi régiója közül, felzárkózási uitemük sokkal gyorsabb a legfejlettebb európai régiókhoz. Ezen feluil e régiók 
Schneider Gábor : Formálódó új európai növekedési központok? A közép-európai térség

metropoliszrégióinak sajátosságai és kihívásai. - Tér és Társadalom 24. évf. 2010/1. 155-173. p.

156 Kitekintö

TÉT XXIV. évf. 2010

nemzetközi együttmúködése is a legintenzívebb a térségben, ami funkcionális munkamegosztáson és specializáción alapul (Enyedi 2003, 5). Elemzésünkben a Bécsi régió, a Közép-magyarországi régió, a Mazóviai vajdaság, a Prágai régió és a Pozsonyi régió országon belïli különleges helyzetét mutatjuk be oly módon, hogy egyben egymással összehasonlíthatóvá is tessziü őket a területi tơke vizsgálatával. Amolyan legjobb példaként emeljük ki a Bécsi régiót, amely eltérő történelmi fejlődés okán Közép-Európa legfejlettebb növekedési központja.

$\mathrm{Az}$ uniós fejlesztéspolitika rendszerében mélyreható változások megindulása érzékelhetö. A versenyképességi célok egyre következetesebb megjelenítését érzékeljuik, amely minden bizonnyal változással lesz a kohéziós politika jelenlegi rendszerére. Így például a meglévő fejlesztési struktúrák átalakulásának irányába hatnak a következő programozási célok: az integrált szemlélet fokozatos kiteljesedése, a terület-alapú szempontok érvényesítése, illetve a transz- és interregionális, valamint a határ menti egyuittmúködési programok számának és intenzitásának folyamatos növelése. Mindezen lépések folyamatos elmozdulást eredményeznek a fejlesztéspolitika bázisának számító NUTS2-es területi szintről.

A nagyvárosi régiók versenyképessége egyre komplexebbé vált, a gazdasági kérdések mellett szociális, társadalmi, kormányzási és fejlesztési szempontok is megjelentek (Begg 1999; Camagni 2009; Szirmai 2009). Mindez olyan duális elemzési szempont alkalmazását indokolja, amely a társadalmi és a területi tỏke együttes vizsgálatát teszi lehetővée

$\mathrm{Az}$ interdiszciplináris megközelítésünkben a területi adottságok (területi tőke) mellett a társadalmi tőke sajátosságait meghatározó struktúrák - mint például a többszintü regionális kormányzás, a hálózati kapcsolatok megerösítése stb. - összekapcsolására kerül sor. Európa regionális fejlődésében ugyanis jól látható tendencia, hogy a területi sajátosságokon alapuló, egyedi értékeiből merítő, sokszínủ régiók Európája felé halad.

Tanulmányunkban az ESPON és METREX empirikus kutatásokat, valamint Roberto Camagni (2009), Iain Begg (1999) és Harald Baldersheim-Pawel Swianiewicz (2003) területi sajátosságokat összefoglaló elméleteit felhasználva mutatjuk be az európai növekedési központok sajátosságait. A közép-európai növekedési központokat a geográfiai elhelyezkedés, a térszerkezet, az infrastrukturális fejlettség és a humán erőforrás jellege, valamint az egyes régiók innovációs és kutatás-fejlesztési adottságai alapján értékeljük és hasonlítjuk össze. Rámutatunk, hogy a régiók sajátos karaktere jelentősen meghatározta a regionális fejlỏdést és a fejlesztési lehetőségeket, befolyásolva ezzel a regionális versenyképességet (ESPON 2007; Camagni 2009). Továbbá, hogy minél több speciális funkcióval rendelkezik egy régió, annál meghatározóbb gazdasági és politikai központként müködik ${ }^{5}$.

A régiók kormányzási struktúrája a fejlesztéspolitikai célok végrehajtásában kulcsfontosságúvá vált. A területi kormányzás szereplői a kibővült partnerségi hálózatok eredményeként fokozatosan megerösödtek. A nagyvárosi régiók kiterjedt transznacionális kapcsolatokkal bírnak, amelyben a hagyományos közigazgatási szereplők mellett a civil és a magán szféra szereplöi is képviseltetik magukat. Fontos 
Schneider Gábor : Formálódó új európai növekedési központok? A közép-európai térség

metropoliszrégióinak sajátosságai és kihívásai. - Tér és Társadalom 24. évf. 2010/1. 155-173. p.

TÉT XXIV. évf. 2010 a 1

Kitekintö

157

ezért az aktorok kapcsolatának mind horizontális, mind vertikális aspektusban történő elemzése. A régiók érdekérvényesítő képessége nemcsak az egyes országokon belül növekedett meg, hanem, mint ahogy német, spanyol, olasz, dán vagy francia, portugál példákkal igazolható, aktív formálói is lettek az uniós döntéshozatalnak. Egyre komplexebb kormányzási rendszerekkel találkozhatunk, amelyet Ágh Attila a „glokalizmus jelenségeként” ábrázol (Ágh 2010). Ily módon a szubnacionális régiók transzregionalizációs folyamatának lehetünk tanúi helyi és térségi szinergiák kiaknázásával.

\section{A metropoliszrégiók, mint növekedési központok meghatározása}

A nagyvárosi régiók és az urbanizáció megerősödését jelzi, hogy az Európai Unióban 2020 -ig a lakosság $80 \%$-a városlakó lesz. Mindez jelentős súlyponti eltolódást eredményez a rurális és a városi térségek viszonyában, amelyet a kohéziós és elörehaladási jelentések egyre markánsabban tartalmaznak (Európai Bizottság 2008b; 2009c).

Az európai területi fejlődést egyre jelentősebb mértékben befolyásolják a növekedési központok (ESPON 2006a; 2007; METREX 2007), amelyek regionális centrumokként dinamizálni képesek a vonzáskörzetükbe tartozó városi térségeket ${ }^{6}$.

A növekedési központok meghatározásához a metropoliszrégiók fogalma áll a legközelebb. Elemzésünkben ezért a növekedési központ megfelelöjeként használjuk a metropoliszrégiót. Értelmezésünkben a metropoliszrégió egy rendkívül erős tőke, gazdasági, humán és infrastrukturális koncentrációval rendelkező funkcionális nagyvárosi térség, amely több milliós lakosságú?. A növekedési központok esetében tehát olyan régiókról beszélhetünk, amelyek már meghaladják az európai területistatisztikai rendszer általunk vizsgált NUTS 2-es szintjét ${ }^{8}$.

A növekedési központok jellemzéséhez elengedhetetlen annak szubregionális és transzregionális tagolása. Szubregionális szinten a három szintủ városhálózati struktúra bemutatásával jellemezzük a növekedési központokat. A térstruktúrában beöltött szerepük alapján ugyanis a régiók az alábbi rendezőelvek mentén csoportosíthatók:

- Nemzetközi szerepkört ellátó régió.

- Regionális, térségi vonzáskörzettel rendelkező régió.

- Helyi fejlesztési pólus.

A térstruktúra alulról integrált módon épül fel. Nemzetközi szinten meghatározó szerepet a metropoliszrégiók töltenek be, amelyek változatos körét az 1. ábra szemlélteti. A térstruktúrában a metropoliszrégiókat követik azok a regionális központok, amelyek gazdasági és társadalmi térformáló ereje továbbra is meghatározó, de a nemzetközi szerep helyett elsősorban az ország egy-egy területének irányítását végzik. Végezetül a térszerkezet bázisai azok a helyi pólusok, amelyek települési és kistérségi szinten töltenek be irányító és központi funkciókat. A nemzetközi térstruktúra modellje akkor müködik hatékonyan, ha az egyes szintek integráltan egymásba. 
Schneider Gábor : Formálódó új európai növekedési központok? A közép-európai térség metropoliszrégióinak sajátosságai és kihívásai. - Tér és Társadalom 24. évf. 2010/1. 155-173. p.

épülnek, ily módon az egyes metropoliszrégiókban több meghatározó helyi pólus, esetleg térségi központ is múködik.

1. ÁBRA

A nagyvárosi térségek rendszerének bemutatása - a térstruktúra hálózati felépülése (The Classification of the Metropolitan Growth Poles - the Network

of Spatial Structure)

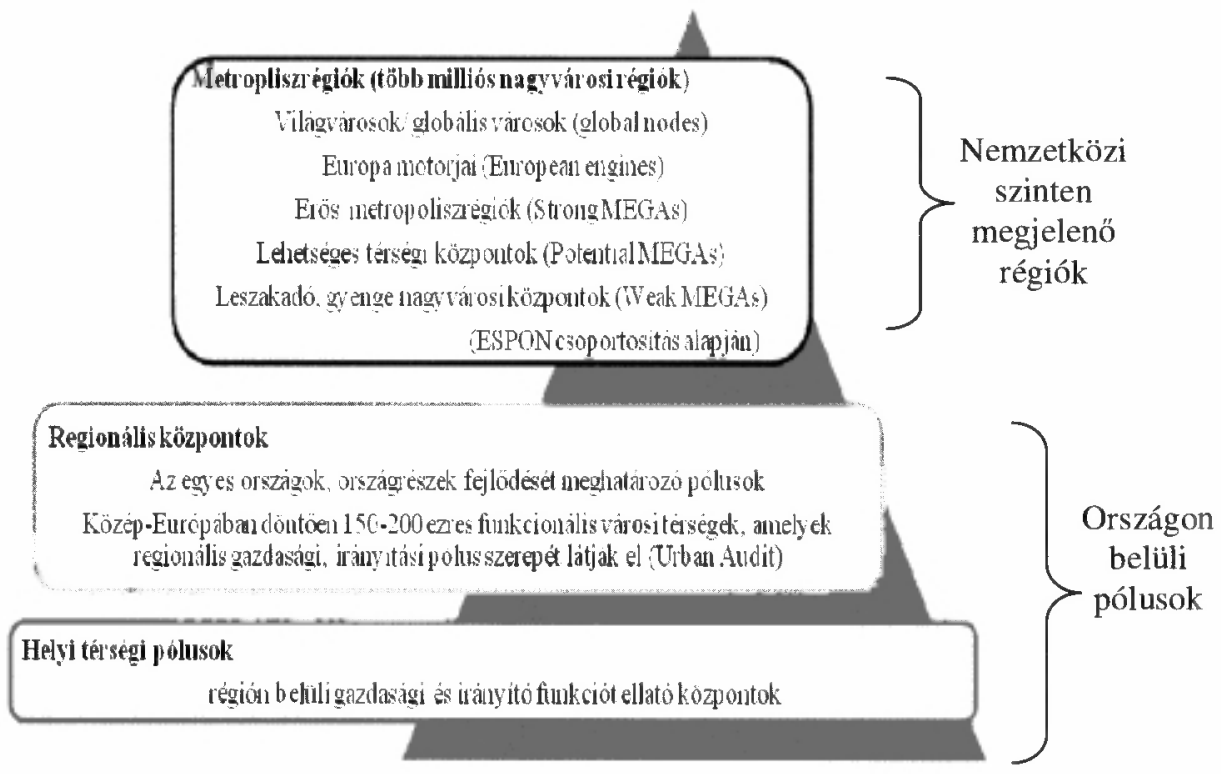

Forrás: Schneider (2009).

A transzregionális megközelítésben Európa több gazdasági térségre és övezetre osztható fel. Nagyságuk alapján mega-, makrorégiókat különböztethetünk meg. A megarégiók rendszerint egész kontinenseket átölelö gazdasági térségek (NAFTA, MERCOSUR, ASEAN, Európai Gazdasági Térség stb.), amelyekkel e tanulmány keretei között nem foglalkozunk. A makrorégiók jogilag lehatárolt, országok mentén meghatározott gazdasági övezetek. Olyan földrajzilag összefüggő térségek, amelyekben a növekedési pólusok gazdasági, kereskedelmi és kulturális kapcsolatok mentén együitmüködésben vannak egymással.

Az Európai Balti Stratégiával jelent meg elöször a funkcionális markorégió fogalma az Európai Unióban; e dokumentum országok mellett (helyett) már régiók és fejlesztési tengelyek speciális gazdasági kapesolatait tartalmazza. A funkcionális makrorégió (horizontális) meglévő intézményi struktúrák mentén formálódó térség. Eltéröen a makrorégiótól a térségi együttmüködések javítására fejlesztési források is rendelkezésre állnak, jellemzöen az európai transzregionális együttmüködést elösegítő uniós fejlesztési források keretéböl. A hagyományos értelemben vett makrorégióval szemben ezt a térséget funkcionálisan, vagyis konkrét célok és prioritások mentén alakították ki. 
Schneider Gábor : Formálódó új európai növekedési központok? A közép-európai térség

metropoliszrégióinak sajátosságai és kihívásai. - Tér és Társadalom 24. évf. 2010/1. 155-173. p.

TÉT XXIV. évf. 2010 『 1

Kitekintö

159

\section{A növekedési központok tulajdonságai}

A globalizált világgazdaság jellemző vonása, hogy nem elsősorban államokban, hanem gazdasági központokban öltenek formát (Friedmann-Wolff 1982, 310). John Friedmann elhíresült ún. világváros elméletében (The World City Hypothesis) (Friedmann 1986) lényegében megalapozta a növekedési központokra a mai napig is használt feltételeket. Ezek a következök:

- Meghatározó pénzügyi központ szerepének betöltése;

- Transznacionális vállalatok székhelyei, regionális központjai;

- Nemzetközi szervezetek és intézmények központjai;

- A szolgáltatási szektor dominanciája;

- Termelési központ szerepe, döntéshozatali és irányító funkcióval;

- Közlekedési csomópont;

- Jelentős népességszám és népsürüség.

Az ESPON hetvenhat európai növekedési központot határozott meg Európában. Az uniós kutatás nagyban támaszkodik John Friedmann elméleti munkájára, amely hét rendezőelvet alakított ki a metropoliszrégiók csoportosítására (ESPON 2004). Ezek a következök:

- Magas népességszám. Azokat a magas népsürüségi rátájú régiókat tekintik metropoliszrégióknak, amelyek, ,jóval" meghaladják az uniós területi átlagot, a $107 \mathrm{fö} / \mathrm{km}^{2}-\mathrm{t}^{9}$;

- Közlekedési infrastruktúra fejlettsége és a nemzetközi elérhetöség;

- Gazdasági fejlettség;

- Döntéshozó központok aránya a magánszférában;

- Nemzetközi szervezetek súlya;

- Turizmus és idegenforgalmi vonzerö;

- Regionális tudásbázis, a felsőfokú intézmények száma, továbbá a humán erőforrás koncentrációja és a kutatás-fejlesztésben dolgozók aránya.

Az ESPON az ipari termelés arányát, a közlekedés fejlettségét, az egyetemek és oktatási intézmények számát, az adott régió szerepét a nemzeti vagy a nemzetközi döntéshozatali folyamatokban, a központi igazgatás szerepét (elsősorban a transznacionális vállalatok tekintetében), valamint a turizmus arányát vizsgálta. A kutatási empíriák szerint a gazdaságilag legfejlettebb régiókban az ipari termelés szerkezetében hangsúlyeltolódás ment végbe az elmúlt évtizedekben (Enyedi 2003; ESPON 2007). Ezekben a régiókban nemzetközi összehasonlításban is kiemelkedő arányú a magas fejlettségú, tudás-intenzív szektorok súlya. Michael Krätke a nagyvárosi régiók fejlődését elemezve vizsgálataiban rámutatott azokra a termelés-szerkezeti tendenciákra, amelyek a technológiai szerkezetváltás nyomán jelentek meg (Krätke 1995). A nagyvárosi régiók legjellemzőbb ilyen sajátossága a szolgáltatási szektor döntő súlya az ún. termelési szektor struktúrájában ${ }^{10}$. 
Schneider Gábor : Formálódó új európai növekedési központok? A közép-európai térség

metropoliszrégióinak sajátosságai és kihívásai. - Tér és Társadalom 24. évf. 2010/1. 155-173. p.

160 Kitekintö

TÉT XXIV. évf. 2010

Jól látható általános jelenség a nagyvárosi régiókban a „,klasszikus ipari funkciók” fokozatos kitelepülése. Első ütemben a regionális vonzáskörzetbe (agglomerációs térségbe) települnek át a régióközpontokból a hagyományos termelési egységek, majd következő lépésben a régión túli (periférikus) térségekbe. A fejlett nagyvárosi régióban alkalmazott (ipari) termelés korszerủ technológiákon alapul, magas szakképzettséget igényel. Ennek empirikus szemléltetésére talán az egyik legmegfelelőbb az Európai Bizottság gazdasági és társadalmi kohéziót vizsgáló Ötödik előrehaladási jelentése, amely a konvergencia, az átmeneti és a regionális versenyképesség, mint régiókategóriák legfontosabb jellemzőit hasonlította össze (Európai Bizottság 2008b). A növekedési központok tulajdonságait legjobban a regionális versenyképesség régiók jelenítették meg.

$\mathrm{Az}$ ún. regionális versenyképesség régiókban a pénzügyi és üzleti szektorhoz kapcsolódó szolgáltatások esetében a legmagasabb a foglalkoztatottsági ráta, amely meghaladja az 50-60\%-ot is. Fontos, hogy a magas hozzáadott értékủ csúcstechnológiákat elő́llító termelési ágazatok ${ }^{11}$ is döntően a versenyképességi régiókban koncentrálódnak. További sajátossága a regionális versenyképesség régióknak, hogy az ipar termelése a bruttó regionális termelésben megegyezik a konvergencia régiók termelési arányával, de ezt lényegesen kevesebb foglalkoztatottal és fejlettebb technikai eszközökkel állítják elő. A regionális versenyképességi régiók emellett átlagosan háromszor többet költenek kutatás-fejlesztésre, mint a konvergencia régiók.

Speciális helyzetben a fővárosi régiók vannak, amelyek kiterjedt nemzeti, nemzetközi funkciókkal rendelkeznek. Ehhez társulnak még a regionális és települési igazgatási szerepek, amelyekkel nemzetközi és szupranacionális, nemzeti, regionális és települési funkciókat, valamint feladatokat látnak el (Ágh 2005; Szente 2007). A globalizált gazdasági folyamatok sajátosságának is tekinthetjük az egyes gazdasági központok összekapcsolódásának igényét, a pólusokban megjelenő erőteljes koncentrációját a tudás- és a pénzügyi tőkének, a humán erőforrásnak és a kutatás-fejlesztésnek. Ennek transznacionális megnyilvánulása a földrajzilag összefüggő makrorégiók kialakítása, ahol a regionális fejlesztési pólusok összekapcsolódnak egymással.

Ugyanakkor az ESPON kutatások azt is megállapítják, hogy a régiók belső térstruktúrájában a helyi pólusoknak kiemelt szerepük van. Az arányos területi megoszlással csökkenthető a területi aszimmetria. A növekedési központok vizsgálatának további gyakorlati tanulsága ugyanis, hogy ezek leggyakrabban a mellettük lévő hasonló fejlesztési csomópontokkal alakítanak ki különbözö hálózati együttmủködési formákat funkcionális kapcsolatok mentén.

A kis- és közepes lakosságszámú országokban a többmilliós fỏvárosi régiók monocentrikus helyzetben vannak. A magyar és a cseh példához hasonló struktúrát láthatunk például Dánia, Portugália vagy Görögország esetében. A több tíz milliós népességủ országok esetében már árnyaltabb képet kapunk. Ide sorolható Németország, Hollandia, Olaszország és Spanyolország, illetve Közép-Európából Lengyelország. Ezek az országok térstruktúrájukat tekintve policentrikus jellegủek, több meghatározó súlyú pólussal - regionális központtal - rendelkeznek. Ugyanakkor Franciaország vagy Anglia esetében továbbra is kiemelt szerepkörben vannak 
Schneider Gábor : Formálódó új európai növekedési központok? A közép-európai térség metropoliszrégióinak sajátosságai és kihívásai. - Tér és Társadalom 24. évf. 2010/1. 155-173. p.

TÉT XXIV. évf. 2010 घ 1

Kitekintó 161

a fơvárosi régiók. Az államberendezkedés formája is erős befolyással van arra, hogy az egyes országokban a régiók fejlettsége között milyen mértékủ az eltérés. A föderális vagy regionális decentralizált országokban a policentrikus(abb) térstruktúra a jellemző, míg a centrális, unitárius államok esetében döntően a fővárosi régiók azok, amelyek domináns, monocentrikus régiókként múködnek, erős térségi és gazdasági aszimmetriát kialakítva.

A területi különbségek gyakori velejárója a főváros-vidék szembenállás is. Közép-Európára jellemző, hogy a fővárosi régiók országuk legfejlettebb régiói, és hogy a fejlettségbeli különbség a legfejletlenebb régióval szemben az elmúlt évtizedben folyamatosan tovább növekedett (ESPON 2006a; EUROSTAT 2009). A konfliktust erősítette, hogy az európaizáció és a strukturális politika forrásai sok esetben a legfejlettebb régiók felzárkózását segítették elő.

Ezek a fóvárosi régiók tudtak az EU15 fejlettségi szintjéhez leginkább felzárkózni. Ebben magas és képzett lakosságszámuk, irányítási és szolgáltatási központ funkciójuk nagy szerepet játszott. Meghatározó feltétel továbbá, hogy az egyes növekedési központok Európa mely térségébe, övezetébe tartoznak. Empirikus kutatásokkal alátámasztott, hogy a gazdaságilag leginkább homogén nyugat-európai térségekben a legszélesebb körü az együttmüködés az egyes növekedési pólusok között (Mehlbye 2000; ESPON 2007; Európai Bizottság 2009a). Az ún. Globális Integrációs Zónán (Global Integration Zone, GIZ) belül érvényesül leginkább a régiók közötti specializáció és funkcionális munkamegosztás. A GIZ-re jellemző a legmagasabb fokú térségi specializálódás, a magas fokon képzett humán erőforrás koncentráció és az infrastrukturális hálózat, melynek sủrủsége gyors közlekedési lehetőségeket és info-kommunikációs összeköttetést biztosít. Ez utóbbi vonatkozásában jelenik meg az ún. „csillagpont” vagy „,kerékagy” (hub) fogalma, amely a legfejlettebb növekedési központokra jellemző adottság (METREX 2007).

Az EUROSTAT és az ESPON Atlas és az OECD Territorial review empirikus kutatásai igazolták, hogy a korszerú info-kommunikációs és infrastrukturális hálózatok mentén jelentős kutatás-fejlesztési potenciál, magas fokú, korszerủ technológiák széles körủ alkalmazása terjedt el, amely jelentős regionális versenyelőnyhöz juttatta a legfejlettebb gazdasági térségeket és a bennük érintett régiókat ( $E S P O N$ 2006a; EUROSTAT 2009; OECD 2009).

A gazdasági kapcsolatok azokban a transzregionális térségekben, makrorégiókban a legintenzívebbek, amelyek gazdasági és társadalmi fejlettség szempontjából a legegységesebbek és a fejlettségi szintjük a legmagasabb. Az Európai Térség-fejlesztési Koncepció (European Spatial Development Perspective), az EPSON Zoom In és a METREX PolyMETREX Plus programjai alapján végzett rendszerezésünk pedig jól mutatja Európa gazdasági térségeinek sokféleségét, eltérő fejlettségi állapotát (1. táblázat). Az egyes gazdasági térségek eltérỏ fejlődési irányt jártak be, amelyben nagy szerepük van a gazdasági, társadalmi és kulturális hagyományoknak és okoknak. 
Schneider Gábor : Formálódó új európai növekedési központok? A közép-európai térség

metropoliszrégióinak sajátosságai és kihívásai. - Tér és Társadalom 24. évf. 2010/1. 155-173. p.

162 Kitekintö

TÉT XXIV. évf. 2010 — 1

\section{TÁBLÁZAT}

Az Európai Unió gazdasági és földrajzi térségeinek, övezeteinek besorolása

(The Classification of Economic Areas and Territorial Spaces of the European Union)

\begin{tabular}{|c|c|c|c|}
\hline Besorolás & ESDP alapján & $\begin{array}{c}\text { ESPON Zoom In } \\
\text { alapján }\end{array}$ & PolyMETREX alapján \\
\hline $\begin{array}{l}\text { Európa központi } \\
\text { része az EU15-ben, } \\
\text { amely a klasszikus } \\
\text { centrum (GIZ) } \\
\text { térség fogalmát } \\
\text { jelenti }\end{array}$ & 1) Északnyugati & $\begin{array}{l}\text { 1) Közép-európai } \\
\text { övezet }\end{array}$ & $\begin{array}{l}\text { 1) Globális Integrációs } \\
\text { Zóna } \\
\text { a) Magtérség } \\
\text { b) Rajna - Észak- } \\
\text { Alpok } \\
\text { c) Niedersachsen }\end{array}$ \\
\hline $\begin{array}{l}\text { London és térségét } \\
\text { leszámítva az Egye- } \\
\text { sült Királyság és } \\
\text { Írország, amely az } \\
\text { ESPON és } \\
\text { METREX lehatáro- } \\
\text { lásnál kibövül az } \\
\text { Északi-tenger or- } \\
\text { szágaival }\end{array}$ & 2) Brit övezet & $\begin{array}{l}\text { 2) Északnyugati } \\
\text { zóna }\end{array}$ & 2) Északi szigetek \\
\hline $\begin{array}{l}\text { Az északi államok } \\
\text { térsége. Kezdetben } \\
\text { a skandináv orszá- } \\
\text { gok és Finnország, } \\
\text { majd a Baltikum }\end{array}$ & $\begin{array}{l}\text { 3) Északi tér- } \\
\text { ség }\end{array}$ & $\begin{array}{l}\text { 3) Dél-skandináv } \\
\text { - balti övezet }\end{array}$ & $\begin{array}{l}\text { 3) Baltikum térsége } \\
\text { a) Nyugat-Baltikum } \\
\text { b) Kelet-Baltikum }\end{array}$ \\
\hline Dél-Európa térsége & $\begin{array}{l}\text { 4) Mediterrán } \\
\text { térség }\end{array}$ & $\begin{array}{l}\text { 4) Ibériai térség } \\
\text { 5) Déli térség } \\
\text { (Biscay öböllel) }\end{array}$ & $\begin{array}{l}\text { 4) Ibériai-félsziget } \\
\text { a) mediterrán } \\
\text { b) atlanti } \\
\text { c) déli része } \\
\text { 5) Biscay öböl }\end{array}$ \\
\hline & & $\begin{array}{l}\text { 6) Potenciális } \\
\text { keleti övezet }\end{array}$ & $\begin{array}{l}\text { 6) Alpok-Mediterrán övezet } \\
\text { a) Rhone - Alpok } \\
\text { b) Déli Alpok térsége } \\
\text { c) Közép-Mediterrán } \\
\text { térség } \\
\text { 7) Égei térség }\end{array}$ \\
\hline $\begin{array}{l}\text { Az általunk közép- } \\
\text { európai térségként } \\
\text { definiált földrajzi } \\
\text { terület az uniós } \\
\text { kutatásokban }\end{array}$ & - & $\begin{array}{l}\text { 7) Kelet-közép- } \\
\text { európai térség } \\
\text { 8) Lengyel zóna } \\
\text { 9) Duna medence }\end{array}$ & $\begin{array}{l}\text { 8) Közép-európai térség } \\
\text { a) Berlin és térsége } \\
\text { b) Szász háromszög } \\
\text { c) Dunai térség } \\
\text { d) Lengyelország }\end{array}$ \\
\hline
\end{tabular}

Forrás: ESPON (2006b); METREX (2007). 
Schneider Gábor : Formálódó új európai növekedési központok? A közép-európai térség

metropoliszrégióinak sajátosságai és kihívásai. - Tér és Társadalom 24. évf. 2010/1. 155-173. p.

TÉT XXIV. évf. 2010 — 1

Kitekintö

163

\section{Az európai növekedési központok kategorizálása}

Az európai régiók csoportosítása alkalmával lényeges szempontnak tartjuk a transznacionális és szubnacionális értelmezés megkülönböztetését. A transzregionális szemlélet esetében mega-, illetve funkcionális makrorégiókat ${ }^{12}$ különböztethetünk meg. Ez több száz milliós lakosságú gazdasági és földrajzi térségeket foglal magában. Ennek részét képezik a szubnacionális régiók, amelyek a térstruktúrát alkotó nagyvárosi régiók.

Az uniós városhálózati piramis tetején az ún. globális csomópontok (global nodes) (ESPON 2004; 2006a; METREX 2005) állnak. Ezeket a metropoliszrégiókat nevezhetjük világvárosoknak is. Európában a Greater London régió, illetve a Párizst magában foglaló Ile-de France régió tartozik ebbe a csoportba (2. táblázat).

Az uniós városhálózati struktúrában a globális csomópontokat az „Európa motorjaiként" (European Engines) nevezett metropoliszrégiók követik, amelyek kiemelkedó gazdasági és elérhetöségi mutatókkal rendelkeznek, magasan képzett humán erőforrás koncentráció jellemzi őket regionális sajátosságokkal. Ugyanakkor lakosságszámuk és/vagy nemzetközi vonzóképességiik tekintetében elmaradnak a világvárosoktól. Ilyen típusú metropoliszrégióból az ESPON tizenhetet tart nyilván (ESPON 2005). A „globális csomópontok” és az „Európa motorjaiként” jellemzett régiók Európa legfejlettebb és legversenyképesebb metropoliszrégiói. KözépEurópából egyeduul a Bécsi régió tartozik ebbe a kiemelt körbe. Ezek a metropoliszrégiók alkotják az európai térstruktúra csúcsát, amelyet legelső csoportként tart nyilván az uniós terminológia. Fontos, hogy ezek a metropoliszrégiók már nem csak Európa legfejlettebb gazdasági térségében, a Pentagon térségben összpontosulnak, hanem például ilyen északon a Koppenhágai és a Stockholmi régió; a mediterrán térségben a Madridi, a Barcelonai és a Római (Laziói) régió (2. táblázat). Lakosságszámukban is jelentős különbségek vannak, amely másfél és öt millió fő között oszlik meg.

Ún. „Erös MEGÁ-knak” (Strong MEGAs) tekinthetők azok a nagyvárosi régiók, amelyek egy-két sajátosság tekintetében versenyképesek. Rechnitzer János például a humán erőforrás magas arányát emeli ki (Rechnitzer 2007), de további ilyen jellemzök az elérhetőség, vagy a népességszám, vagy a döntéshozatali funkciók. Ugyanakkor az összhatás tekintetében már gyengébbek az Európa motorjaiként megnevezett metropoliszrégióknál. Erös MEGA-ként az ESPON nyolc nagyvárosi régiót kategorizált, amelyek a második csoportot alkotják.

A harmadik csoportba az uniós terminológia ún. „Potenciális MEGA központokként" (Potentional MEGAs) határozza meg azokat a metropoliszrégiókat, amelyek több versenyképességi tényezóben is elmaradnak az első két csoporttól. Alacsonyabb gazdasági fejlettség, rosszabb elérhetôség, kevesebb nemzetközi vállalat és intézmény regionális döntéshozatali központja a jellemzö. Ebbe a körbe tartozik a kỏzép-európai fövárosi régiók közül a Közép-magyarországi régió, a Mazóviai vajdaság és a Prágai régió. Az EU27 térségéből összesen huszonhat metropoliszrégiót sorol az ESPON a városhálózati struktúra harmadik szintjére (2. táblázat). 
Végezetuil azok a nagyvárosi régiók, - amelyek az uniós átlag alatti gazdasági fejlettséggel rendelkeznek, továbbá strukturális gondokkal jellemezhetỏk, valamint nemzetközi elérhetöségük sem megfelelö - ún. gyenge metropoliszokként (weak MEGAs) szerepelnek a szakirodalomban. Ide tartozik például a román vagy a bolgár fóváros régiója, vagy azok a korábban meghatározó ipari nagyvárosi régiók, amelyekben acélés vaskohászat, vagy bányászat dominált. Az ESPON csoportosítás a Pozsonyi régiót is ide sorolta. A negyedik csoportba huszonhárom metropoliszrégió került.

\section{TÁBLÁZAT}

Az európai metropoliszrégiók besorolásáról (The Classification of the Europen Metropolregions)

\begin{tabular}{|c|c|c|}
\hline $\begin{array}{c}\text { Metropoliszrégió típusa } \\
\text { és besorolása az európai } \\
\text { térstruktúrában }\end{array}$ & $\begin{array}{l}\text { Metropoliszrégiók } \\
\text { száma }\end{array}$ & $\begin{array}{c}\text { Példák a Globális Integrációs } \\
\text { Zónán (GIZ) belüli, illetve az } \\
\text { azon kivüli földrajzi térségek } \\
\text { metropoliszrégióiról }\end{array}$ \\
\hline $\begin{array}{l}\text { Globális csomópont - } \\
\text { Elsö csoport }\end{array}$ & 2 & $\begin{array}{l}\text { Greater London, Ile-de France } \\
\text { régió }\end{array}$ \\
\hline \multirow[t]{2}{*}{$\begin{array}{l}\text { Európa motorjai - Elsõ } \\
\text { csoport }\end{array}$} & \multirow[t]{2}{*}{17} & $\begin{array}{l}\text { GIZ-en belül: Hamburgi, } \\
\text { Müncheni, Milánói és Amsz- } \\
\text { terdami régió stb. }\end{array}$ \\
\hline & & $\begin{array}{l}\text { GIZ-en kívül: Koppenhágai, } \\
\text { Stockholmi, Madridi, Római } \\
\text { és Bécsi régió }\end{array}$ \\
\hline \multirow{2}{*}{$\begin{array}{l}\text { Erös MEGÁ-k - } \\
\text { Második csoport }\end{array}$} & \multirow[t]{2}{*}{8} & GIZ-en belül: Torinoi régió \\
\hline & & $\begin{array}{l}\text { GIZ-en kívül: Dublini-, Athé- } \\
\text { ni, Oslói, Genfi régió }\end{array}$ \\
\hline \multirow[t]{2}{*}{$\begin{array}{l}\text { Potenciális MEGÁ-k - } \\
\text { Harmadik csoport }\end{array}$} & \multirow[t]{2}{*}{26} & $\begin{array}{l}\text { GIZ-en belül: Rotterdami, } \\
\text { Lyoni, Brémai régió }\end{array}$ \\
\hline & & $\begin{array}{l}\text { GIZ-en kívüil: Prágai régió, } \\
\text { Mazóvia vajdaság, KMR, } \\
\text { Lisszaboni, Glasgowi és a } \\
\text { Valenciai régió }\end{array}$ \\
\hline \multirow{2}{*}{$\begin{array}{l}\text { Gyenge MEGÁ-k - } \\
\text { Negyedik csoport }\end{array}$} & \multirow[t]{2}{*}{23} & GIZ-en belül: nincs \\
\hline & & $\begin{array}{l}\text { GIZ-en kívuil: Pozsonyi, Szó- } \\
\text { fiai, Bukaresti, Portói, Sevillai, } \\
\text { Vilniusi és Ljubljanai régió }\end{array}$ \\
\hline
\end{tabular}

Forrás: ESPON (2005); Schneider (2009).

A nemzetközi együittmüködésekbe bekapcsolt növekedési központok érdemi módon enyhítették az uniós területi egyenlötlenségeket az Európai Bizottság kohéziós jelentései szerint (ESPON 2004; 2007; Európai Bizottság 2009a; 2009b; 2009c). Ennek eredménye, hogy amíg az 1990-es évek elején a legfejlettebb és a legfejletlenebb térségek esetében növekvő különbségek voltak tapasztalhatók, addig az ESDP 1999-ben - az EU15-ök esetében - már a külöonbségek lassú csökkenéséröl beszélt. ${ }^{13} \mathrm{E}$ tekintet- 
ben azóta is folyamatos felzárkózás mutatkozik az EU15-nél (ESPON 2006a). Az ESPON 1.1.3-as kutatása ugyanakkor azt igazolta, hogy az Európai Unió 2004-es első keleti bóvítésével a legfejlettebb és a legszegényebb régiók közötti gazdasági fejlettségi arány az egy före jutó GDP tekintetében a korábbi 1:10-hez 1:30-ra romlott (ESPON 2005, 23). Ez az arány Románia és Bulgária belépésével még kedvezötlenebbé vált.

\section{Közép-európai növekedési központok sajátosságai}

Közép-Európa úgy zárkózik fel az uniós átlaghoz, hogy a legfejlettebb régiói - a fővárosi régiók - folyamatosan fejlödnek, ezáltal motorfunkciót töltenek be. Eközben az országokon belül viszont fokozatosan mélyül(t) a fejlettségbeli különbség. Az OECD felmérése alapján a legnagyobb különbséget Szlovákia esetében találtuk $^{14}$, amit az EUROSTAT 2009-es Regionális Évkönyve is alátámasztott (EUROSTAT 2009).

A 3. táblázat két markáns dologra hívja fel a figyelmet. Egyfelöl az 1980-as években az Unióhoz csatlakozott Spanyolország és Portugália is sikeres kohéziós politikát tudott folytatni, amely a területi különbségek jelentős csökkenéséhez vezetett ${ }^{15}$.

Másfelöl az újonnan csatlakozott országoknál is a területi különbségek növekedése volt tapasztalható. A közép-európai térségben csak a fövárosi régiók tudtak érezhető felzárkózást és fejlödést elérni. Ugyanakkor motorfunkciójuk korlátozott mértékben érvényesült, a többi régió felzárkózása jól láthatóan lassúbb ütemú.

\section{TÁBLÁZAT}

A területi felzárkózás és leszakadás néhány uniós tagország esetében (Territorial Convergence and Divergence in Case of Some EU Member Countries)

\begin{tabular}{|c|c|c|c|c|c|}
\hline \multicolumn{3}{|c|}{ Konvergencia } & \multicolumn{3}{|c|}{ Divergencia } \\
\hline Ország & Idöszak & $\begin{array}{c}\text { Felzárkózás } \\
\text { mértéke } \\
(\%)\end{array}$ & Ország & Idöszak & $\begin{array}{c}\text { Leszakadás } \\
\text { mértéke } \\
(\%)\end{array}$ \\
\hline Spanyolország & $\begin{array}{l}1980- \\
2007\end{array}$ & 5,1 & Csehország & $\begin{array}{l}1990- \\
2007\end{array}$ & 4,4 \\
\hline Portugália & $\begin{array}{l}1980- \\
2007\end{array}$ & 4,9 & Magyarország & $\begin{array}{l}1990- \\
2007\end{array}$ & 5,1 \\
\hline Olaszország & $\begin{array}{l}1980- \\
2007\end{array}$ & 2,1 & Írország & $\begin{array}{c}1980- \\
2007\end{array}$ & 11,3 \\
\hline \multirow[t]{2}{*}{ Ausztria } & $\begin{array}{l}1980- \\
2007\end{array}$ & 4,4 & Lengyelország & $\begin{array}{c}1990- \\
2007\end{array}$ & 5,5 \\
\hline & & & Szlovákia & $\begin{array}{c}1990- \\
2007\end{array}$ & 8,6 \\
\hline
\end{tabular}

Forrás: OECD (2009). 
Az országos térhálózat valamennyi országban súlyos aszimmetriát mutatott. A fövárosi régiók monocentrikus helyzetben vannak Közép-Európában. Országuk egyetlen nemzetkỏzi funkciókkal rendelkező nagyvárosi régiói (4. táblázat). Milliós lakosságszámmal egyeduil a fővárosi régiók rendelkeznek, a Pozsonyi régiót leszámítva.

Ausztria és Lengyelország esetében találtunk több meghatározó (fél milliós lakosságszámot meghaladó) funkcionális városi térséget, amelyek regionális, térségi feladatokat és adminisztratív funkciókat töltenek be. A policentrikus térstruktúra e két országban tapintható ki a leginkább, ami a föderális államberendezkedésnek köszönhetô, illetve a mezoszinten választott önkormányzati régiók múködésével is magyarázható.

Csehország esetében a fôvárosi régiót leszámítva két regionális pólust találtunk. Szlovákia vizsgálatakor a Pozsonyi és a Kassai régiók kerültek be ebbe a csoportba. Magyarország esetében ugyanakkor nem volt olyan nagyvárosi térség, amely tényleges regionális vonzáskörzettel bírt volna (4. táblázat).

Általánosságban valamennyi közép-európai ország esetében megoldatlan probléma, hogy nincsen, illetve nagyon kevés a fél milliós lakosságszámmal rendelkező nagyvárosi térség, amely megfelelő gazdasági, igazgatási regionális pólusként szimmetrikusabb térstruktúrát alakítana ki.

\section{TÁBLÁZAT}

Az öt közép-európai ország térstruktúrájának összehasonlítása (The Comparison of Spatial Structure in Five Central European Countries)

\begin{tabular}{|c|c|c|c|c|c|}
\hline \multicolumn{2}{|c|}{$\begin{array}{c}\text { Nemzetközi vonzáskörzetü } \\
\text { metropoliszrégió }\end{array}$} & \multicolumn{2}{|c|}{$\begin{array}{c}\text { Regionális vonzáskörze- } \\
\text { tü funkcionális városi } \\
\text { térségek }\end{array}$} & \multicolumn{2}{|c|}{$\begin{array}{l}\text { Helyi térségi fejleszté- } \\
\text { si pólusok }\end{array}$} \\
\hline $\begin{array}{l}\text { KE-i országok } \\
\text { funkcionális } \\
\text { városi térség- } \\
\text { struktúrája }\end{array}$ & $\begin{array}{l}\text { Nemzetközi } \\
\text { kisugárzással } \\
\text { rendelkezö } \\
\text { metropolisz- } \\
\text { régió }\end{array}$ & $\begin{array}{l}\text { Országos } \\
\text { vagy regi- } \\
\text { onális } \\
\text { vonzás- } \\
\text { körzettel } \\
\text { rendelkezỏ } \\
\text { régió }\end{array}$ & $\begin{array}{l}\text { Nagyvárosi } \\
\text { térség } \\
\text { (150-200 ezres } \\
\text { lakosságú } \\
\text { funkcionális } \\
\text { városi térség) }\end{array}$ & $\begin{array}{c}\text { Közepes } \\
\text { városi térség } \\
\text { (50 és } 150 \text { ezer } \\
\text { közötti lakos- } \\
\text { ságú funkcio- } \\
\text { nális városi } \\
\text { térség) }\end{array}$ & $\begin{array}{l}\text { Kisvárosi } \\
\text { térség } \\
\text { (50 ezer } \\
\text { alatti } \\
\text { lakosságú } \\
\text { térség) }\end{array}$ \\
\hline Csehország & 1 & 2 & 1 & 14 & 9 \\
\hline Lengyelország & 1 & 12 & 9 & 29 & 39 \\
\hline Ausztria & 1 & 3 & 2 & 5 & 4 \\
\hline Magyarország & 1 & & 2 & 13 & 26 \\
\hline Szlovákia & 1 & 1 & & 8 & 13 \\
\hline
\end{tabular}

Forrás: ESPON (2007).

A lakosságszám és a gazdasági kapacitás tekintetében aránytalan koncentráció ment végbe a fővárosi régiókban. A közép-európai fôvárosi régiók területi és lakossági arányuknál lényegesen nagyobb súllyal bírnak országuk gazdaságában (5. táblázat). Valamennyi régió esetében kiemelkedik a szolgáltatási szektor dominanciája és a kutatás-fejlesztési kapacitás koncentrációja. 
Schneider Gábor : Formálódó új európai növekedési központok? A közép-európai térség

metropoliszrégióinak sajátosságai és kihívásai. - Tér és Társadalom 24. évf. 2010/1. 155-173. p.

TÉT XXIV. évf. 2010 — 1

Kitekintö

167

\section{TÁBLÁZAT}

A közép-európai fỏvárosi régiók gazdasági túlsúlyának bemutatása

(The Economic Power of Central European Capital City Regions)

\begin{tabular}{|c|c|c|c|}
\hline $\begin{array}{c}\text { Fövárosi régió } \\
\text { (NUTS 2-es lehatáro- } \\
\text { lás alapján) }\end{array}$ & $\begin{array}{l}\text { A fóvárosi régió } \\
\text { által elöallitott } \\
\text { GDP aránya az } \\
\text { orszagos GDP- } \\
\text { hez viszonyítva }\end{array}$ & $\begin{array}{l}\text { A fóvárosi régió } \\
\text { lakosságának } \\
\text { nagysága az } \\
\text { ország népessé- } \\
\text { gének arányá- } \\
\text { ban }\end{array}$ & $\begin{array}{c}\text { A fóvárosi } \\
\text { régió } K+F \\
\text { kapacitása az } \\
\text { országos } \\
\text { teljesítmény } \\
\text { tükrében } \\
\end{array}$ \\
\hline Bécsi régió & $28 \%$ & $16 \%$ & $40 \%$ \\
\hline Mazóviai vajdaság & $26 \%$ & $13,5 \%$ & $30 \%$ \\
\hline $\begin{array}{l}\text { Közép-magyarországi } \\
\text { régió }\end{array}$ & $45,5 \%$ & $28 \%$ & $50 \%$ \\
\hline Prágai régió & & $11,7 \%$ & $40 \%^{16}$ \\
\hline Pozsonyi régió & $26 \%^{17}$ & $11,6 \%$ & $47,7 \%$ \\
\hline
\end{tabular}

Forrás: Saját számítás.

Tekintettel arra, hogy a növekedési központok gazdasági teljesítménye nem jellemezhető egyetlen tervezési-statisztikai régió adataival, ezért a fővárosokat természetes vonzáskörzeteikkel együtt is megvizsgáltuk. Az egy före jutó GDP vásárlóerőparitáson mért idősoros elemzés szemléletesen mutatta a fỏvárosi metropoliszrégiók kiemelkedő fejlettségét. A 2. ábra ugyanakkor némileg árnyalja a fỏvárosi metropoliszrégiók erőfölényét, amikor a fỏvárosokkal összefüggő vonzástérségek gazdasági fejlettségi szintjét is megjeleníti, és az összefüggő gazdasági térségek fejlettségi állapotára vonatkozóan hasznos információkkal szolgál. Így jól látható, hogy a fỏvárosok vonzáskörzete mindenhol szembetủnỏen alacsonyabb fejlettségi mutatókkal rendelkezik. A bemutatott növekedési központokra jellemző technológiai szerkezetváltás, a kutatás-fejlesztés és innováció még mindig a fỏvárosokba koncentrálódnak. A vonzáskörzetek ugyanakkor egyre szorosabb gazdasági és társadalmi kapcsolatban vannak a régióközpontokkal, de valamennyi közép-európai fővárosi metropoliszrégió erőteljesen monocentrikus struktúrájú. Kisebb helyi pólusokat, amelyek gazdasági és irányítási funkciókkal bírnak a Bécset körülvevő Alsó-Ausztria és Burgenland tartományok által kialakított Bécsi metropoliszrégió, illetve a Dunántúl nagyságú Mazóviai vajdaság esetében találtuk. Azonban az osztrák és a lengyel esetben sem tudtak egy policentrikus - több pólusú - metropoliszrégiót kialakítani.

Krätke (1995) és Friedmann (1986; 1995) megállapításai a közép-európai növekedési központok esetében is érvényesültek. A speciális funkciók, a kreatív iparágak, a magas hozzáadott értékủ termelés és a közlekedési csomóponti szerep erőteljesen koncentrálódtak a fővárosi régiókban. Igazolható az a tendencia, hogy a szolgáltatási szektor aránya folyamatosan növekedett, ugyanakkor az ipari termelés szerepe fokozatosan kiszorult a vizsgált régiókból. A legmagasabb hozzáadott értékủ, innováció-orientált szolgáltatásokat a Bécsi és a Prágai régióban találtuk. Ezt megerösíti, hogy a Bécsi régióban több mint 350 nemzetközi intézet, illetve nemzetközi vállalat regionális döntéshozatali és kutatásfejlesztési központja található. Vizsgála- 
Schneider Gábor : Formálódó új európai növekedési központok? A közép-európai térség metropoliszrégióinak sajátosságai és kihívásai. - Tér és Társadalom 24. évf. 2010/1. 155-173. p.

168 Kitekintö

TÉT XXIV. évf. 2010

tunk alátámasztja Lengyel Imre és Rechnitzer János által felállított tipológiát is, hogy a legfejlettebb gazdasági és társadalmi tulajdonságokkal rendelkező fővárosi régiókban mutatható ki az ún. tudásteremtő, innováció-vezérelt regionális struktúra (Lengyel-Rechnitzer 2000; Lengyel 2003).

\section{2. ÁBRA}

A fövárosi régiók összehasonlítása az 1 före jutó GDP vásárlóerö-paritás alapján (The Comparison of Central European Capital City Regions in GDP per Purchasing Power Parity)

Osszehasonlítás az 1 före jutó GDP vásárlóerö-paritás alapján

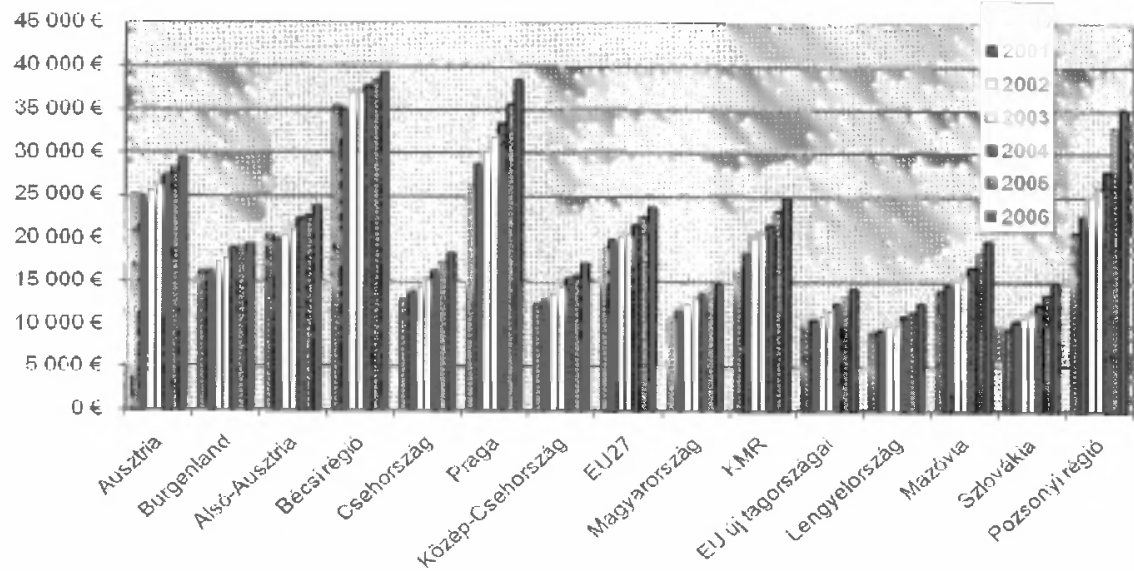

Forrás: EUROSTAT adatok alapján saját szerkesztés.

Ugyanakkor a közép-európai növekedési központok funkcióikat és specializációikat tekintve is még elmaradásban vannak a nyugat-európai országok metropoliszrégiótól. A fent említett Bécsi régiót leszámítva továbbra sem olyan magas a nemzetközi döntéshozatali központok száma. A Prágai régióban és a Közép-magyarországi régióban meghatározó súlyú a szolgáltatási központok aránya, amelyek regionális szinten látnak el konkrét feladatokat. A Pozsonyi régióban az ipari termelés mértékét találtuk jelentősebbnek, amely az autóipari beszállítói klaszterrel hozható összefüggésbe, ugyanakkor a magas hozzáadott értékủ szolgáltatási ágazatok kisebb súlyúak voltak. A Mazóviai vajdaság esetében pedig a nagyvárosi régióknál szokatlanul erös mezőgazdasági szektorral találkoztunk, amely a régióban foglalkoztatottak 19,1\%-ának adott munkát. A lengyel fövárosi régióban jelentős fejlettségi különbségek vannak, a régió valójában egy fejlett fővárosi térségre és egy rurális területre bontható.

Valamennyi fővárosi régió kiváló elérhetőséggel rendelkezik - saját országa viszonylatában. Az elérhetőség területi adottságait tekintve a Közép-magyarországi régió rendelkezik a legtöbb transzeurópai közlekedési hálózati csomóponttal, amely versenyképességet növelö lehetőség. A közlekedési infrastruktúra-hálózat fejlettsége - az országos fejlettséghez viszonyítva - mindenütt átlagon felüli. A Bécsì régiót 
Schneider Gábor : Formálódó új európai növekedési központok? A közép-európai térség

metropoliszrégióinak sajátosságai és kihívásai. - Tér és Társadalom 24. évf. 2010/1. 155-173. p.

TÉT XXIV. évf. 2010 曰 1

Kitekintö

169

leszámítva ugyanakkor a régión belüli közlekedés - az elővárosi közlekedési együttmüködések - a másik négy fövárosi régió esetében továbbra is fejlesztendỏ szempont.

\section{A közép-európai növekedési központok elött álló kihívások-elmélyí- tett specializáció és további együttmüködések}

Bemutattuk, hogy a növekedési központok szerepét Közép-Európában a fövárosi régiók látják el. Helyzetük speciális, melyet e régiókban összpontosuló területi és társadalmi tőke koncentrációja is jól mutat. Ugyanakkor motorfunkciójukat csak korlátozottan tudják ellátni. Ennek okai közé sorolható többek között, hogy a többszintủ városhálózati struktúra aszimmetrikus, hiányoznak a megfelelő gazdasági vonzerővel rendelkező regionális és helyi pólusok. Másrészről a funkcionális specializáció is csak korlátozott mértékben - fejlesztési tengelyek mentén - alakult ki, melyben a horizontális együttmüködések aránya továbbra is alacsony. Ez utóbbi szempont átvezet minket a társadalmi tőke kiaknázatlanságának problémájára a térségben. A regionális specializációhoz szükséges cross-szektorális kapcsolatok terén valamennyi közép-európai fỏvárosi régió komoly elmaradásban van. Ez a szereplöknek a döntéshozatali folyamatból való távolmaradása, illetve nem kellő mértékủ bevonása kapesán jól tapasztalható.

Az egész közép-európai térségre jellemzö hiányosság, hogy kevés az âtfogó és stratégiai együttmüködés. Ugyan az uniós területi együttmủködést szolgáló projektek segítségével megindultak a határ menti, a transz- és interregionális projektek, a közép-európai fỏvárosok közötti infrastrukturális hálózatok is nagymértékben fejlődtek az elmúlt időszakban, de - a többi európai térséghez viszonyítva - még mindig kevés (funkcionális) együttműködési program van. Jelentősebb transznacionális együttmüködéseknek, amelyek Közép-Európát, mint egy homogénebb gazdasági térség felzárkózását elősegítenék, egyelőre nem lehetünk tanúi. A metropoliszrégiók közötti gazdasági együittmüködések nagysága továbbra is alacsony szintü.

Az Európai Területi Együttmüködés keretében rendelkezésre álló uniós források a növekedési központok közötti együttmủködés ösztönzését - korlátozott nagyságuk okán - sem tudják ellátni. A közép-európai fỏvárosi régiók közül egyedül a Bécsi régió tudott meghatározó nemzetközi kapcsolati hálót maga körül kialakítani.

A Lisszaboni Stratégia és az Európa 2020 Stratégia is olyan fó prioritásokat és célokat fogalmaznak meg, amelyek teljesítése jellemzően a legversenyképesebb régiókhoz köthetö. A közép-európai térségben - a Bécsi régiót leszámítva - ugyanakkor nincsen megfelelỏ hazai és uniós fejlesztési forrás e metropoliszrégiók támogatására, összefüggő gazdasági térségek létrehozására. Az osztrák példa esetében sem nemzeti fejlesztési forrásról beszélhetünk, hanem az együttmüködésben részt vevő tartományok által a területi együttmüködés elmélyítésére szánt támogatásról.

A regionális versenyképesség növelése érdekében indokolt az új programozási időszakban a kohéziós és regionális politikában új eszközök alkalmazása, amelyek a 
legfejlettebb régióközpontok és vonzáskörzetük közötti integrált fejlesztési szempontok megvalósítását is támogatják. Ez nem a konvergencia szempontok feladását jelenti, hanem olyan gazdaság- és fejlesztéspolitikai célok alkalmazását, amelyek képesek tovább dinamizálni a legfejlettebb régiókat, elösegítve ezzel motorfunkciójuk hatékonyabb kiaknázását. A területi kohézió, mint horizontális szempont, ugyanis az egyes régiókra egyedi, differenciált válaszokat javasol, ami a fejlett és a fejletlenebb térségek közötti együttmüködést is ösztönzi. Ez a magyar esetben az egyes regionális operatív programok közötti átjárhatóságot jelentené, továbbá a szektorális programok esetében átfogó területpolitikai szempontok érvényesítését.

A növekedési központok strukturáltabb együttmủködésében meghatározó szerepet játszhat a formálódó új funkcionális makrorégió, a Duna térség. A közlekedés és elérhetőségi szempontok fejlesztésével, továbbá a cross-szektorális kapcsolatok elmélyítésével véleményünk szerint tovább javítható a régiók közötti együttmüködés, s ezáltal a bekapcsolódás az európai metropoliszrégiók rendszerébe. A dunai funkcionális makrorégió egyben érdemi elỏrelépést jelenthet az eurorégiós háttérrel nem rendelkező közép-európai fővárosi régióknak is egy makroregionális együttmúködésben való részvételhez.

A közép-európai növekedési központok kedvezö területi adottságai ellenére sincsen a fővárosi régiók profilja és arculata meghatározva. A nyugat-európai növekedési központok esetében elvárt igény a régiók profiljának és jövőképének pontos meghatározása. E szempontok meglétét ugyanakkor a közép-európai régióknál csak elméleti szinten találtuk meg a fejlesztési programokban. Azok összehangolása és gyakorlati megvalósítása továbbra is megoldásra váró probléma. A régiók komoly versenyben vannak azért, hogy megörizzék, illetve tovább javítsák helyzetüket az állampolgárok, az üzleti szféra, a nemzetközi befektetők vagy a régióba látogató turisták körében. Ezen célokhoz kapcsolódnak a régió attraktivitása és vonzereje, valamint a növekedési képességük és modernizációs törekvéseik. Ennek érdekében egyszerre kell magas gazdasági növekedést és foglalkoztatottsági szintet biztosítaniuk, miközben élhetö környezetet, tartós egyensúlyt és fenntarthatóságot szükséges nyújtaniuk. A növekedés párosul a fenntarthatósággal, és jelentős gazdasági, társadalmi és intézményi szerkezetváltást igényel. Itt olyan szempontok jelentek meg, mint például a tudás- és az információs társadalom kihívásai, vagy a hálózati együttmủködések összetettsége. Napjainkban ehhez párosuló további szempont a hatékony regionális válságkezelés, a munkahelyek megőrzése. A fent említett példák is szemléltetik a regionális versenyképesség összetettségét, valamint a középeurópai fővárosi régiók számára megjelenő átfogó problémákat és kihívásokat.

\section{Jegyzetek}

${ }^{1}$ Az ún. growth pole fogalmát a teriuletfejlesztési szempontok elve alapján növekedési központként vagy centrumként alkalmazzuk. Ugyanakkor például a növekedés-orientált gazdaságfejlesztés a „növekedési pólus" kifejezést használja. 
Schneider Gábor : Formálódó új európai növekedési központok? A közép-európai térség metropoliszrégióinak sajátosságai és kihívásai. - Tér és Társadalom 24. évf. 2010/1. 155-173. p.

2 A tanulmány „A magyar régiók versenyképessége az Európai Unióban” címü 77659 számú OTKA kutatás keretében készülit.

${ }^{3}$ Ausztria helyzetét mindenképpen kủlön kell választani a többi közép-európai államétól az eltérő történelmi fejlöđés okán.

${ }^{4}$ A kérdéskörrel átfogó módon foglalkozunk „A közép-európai fơvárosi régiók versenyképességének vizsgálata. Hogyan növelhetỏ a Közép-magyarországi régió versenyképessége?” címủ PhD dìsszertációban (2009).

${ }^{5}$ Michael Krätke (1995) és John Friedmann (1986; 1995) anyagait felhasználva a helyi adottságok és a régiók specializálódásának kapcsolatát jellemezzük.

${ }^{6}$ Érdemes megemlíteni, hogy Jacques Boudeville elméleti munkájában már az 1960-as években modellezte Franciaországban a növekedési pólusokat (BBR 2004). Kutatásában megállapította, hogy ezek a központok motorfunkciójukat nem tudták kelló módon betölteni, azaz a térség gazdasági fejlödését nem tudták megfeleló módon segíteni. Az Európai Unió és az ESPON az ezredfordulót követően mégis egyre nagyobb hangsúlyt helyezett e nagyvárosi központok megerősítésére.

${ }^{7}$ Az egyes metropoliszrégiók között nagyon komoly eltérések mutatkoznak, amelyek félreértésre is okot adhatnak. A lakosságszám és a nemzetközi funkciók száma alapján ennek a csoportnak tagjai a nemzetközi térstruktúra csúcsán lévő globális városok, illetve világvárosok. A funkcionális nagyvárosi térséget a nagyváros és agglomerációs térségének kapcsolataként jellemeztiik, míg a metropoliszrégiót egy ennél lényegesen nagyobb lakosságszámú és területi egységként.

8

Az Európai Tanács és az Európai Parlament 1059/2003-as rendelete lakossági nagyság alapján alakította ki a térszervezödés struktúráját kötelező jelleggel a NUTS 1-3 szinteken. A 3 milliós lakosságszámot meghaladó térségek kerültek a NUTS 1-es csoportba. A NUTS 2-es csoportba a 800 ezer és a 3 millió közötti lakosságszámú régiók tartoznak.

${ }^{9}$ Az ESPON ezzel kikerüli a kérdést, hogy konkrét lakossági számot határozzon meg.

${ }^{10}$ A primer szektor a mezógazdasági termeléshez kapcsolódik, a szekunder az ipari termeléshez, a tercier a szolgáltatási szektorhoz, az ún. kvaterner szektor pedig a tudásalapú technológián és a kutatásfejlesztésen alapul. Krätke (1995) vizsgálatai alapján a nagyvárosi térségekben a szolgáltatási és az ún. negyedik szektor - az info-kommunikációs ágazat - aránya a legmagasabb.

${ }^{11}$ Elektronikus és optikai felszerelések, orvosi múszerek, repülőgép és ûrkutatás, gyógyszerkészítmények gyártása stb. (Európai Bizottság 2008c).

12 A gazdasági és földrajzi térségek különböznek az EU által definiált funkcionális makrorégióktól. Ez utóbbi kialakítására több próbálkozás is volt, de uniós szinten két ilyen térségről szuiletett döntés: a Balti térségről és a Duna térségról. A funkcionális makrorégiók és a földrajzi, gazdasági térségek közötti legnagyobb kulönbség, hogy amíg az elsőt intézményrendszerrel, uniós fejlesztési projektekkel egységes keretek között - próbálják kialakítani, addig a gazdasági térségek lehatárolása földrajzi, kereskedelmi és közlekedési szempontok mentén történik. Ez utóbbi esetében nincsenek tudatos fejlesztési programok, a területi adottságok határozzák meg az együttmüködés formáit.

13

Az Európai Unióban a területi egyenlötlenségek és a fejlettségbeli különbségek nem új keletủ problémák, már a keleti bövítés elỏtt is jelen voltak. Az 1970-es, nyolcvanas és kilencvenes évek növekvon területi kuilönbségei új területfejlesztési koncepciók térnyerését eredményezték. Ezek a kiegyenlítettebb térstruktúra kialakításával a regionális pólusok megerósítését, valamint a metropoliszrégiók és a vidéki rurális térségek együttmüködését kívánták elősegíteni. Ennek jól látható jele, hogy az 1990-es évek második felétől csökken az EU15 országaiban a legfejlettebb és a legfejletlenebb régiók közötti fejlettségi különbség.

${ }^{14} \mathrm{Az}$ öt fövárosi régió esetében az adott fóvárosi régió és országának legfejletlenebb régiója közötti fejlettségi különbség:

- a Bécsi régió esetében $1,57 \%$;

- a Közép-magyarországi régió (KMR) esetében 2,57\%;

- a Prágai régió esetében 2,68\%;

- a Mazóviai vajdaság esetében 2,32\%;

- a Pozsonyi régió esetében 3,43\% (OECD 2009).

15 Írországban tovább növekedtek a területi különbségek, melyek a fejlett nagyvárosi térségek és a rurális térségek közötti erős gazdasági különbségekkel magyarázhatók. 
Schneider Gábor : Formálódó új európai növekedési központok? A közép-európai térség metropoliszrégióinak sajátosságai és kihívásai. - Tér és Társadalom 24. évf. 2010/1. 155-173. p.

16 A kutatóintézetek kétharmada, a vállalati kutatás-fejlesztési központok több mint harmada található a Prágai régióban.

${ }^{17} \mathrm{Az}$ ország ipari termelésének több mint $40 \%$-át adja a Pozsonyi régió.

\section{Irodalom}

Ágh A. 2005) Budapest, mint európai regionális föváros. - Ágh A. (szerk.) Budapest a Középmagyarországi régióban: A közös versenyképesség perspektívái. IDEA, Budapest. 5-15. o.

Ágh, A. (2010) Danube Strategy as a challenge of globalized locality (glocality): The Europeanization of a Functional Macro-Region in the Danube Valley. Kézirat.

Baldersheim, H.-Swianiewicz, P. (2003) The Institutional Performance of Polish Regions in an Enlarged EU. - Keating, M.-Hughes, J. (eds.) The Regional Challenge in Central and Eastern Europe. Peter Lang, Brüsszel - Bern - Berlin. 121-145. o.

Barta Gy. (2005) Nemzetközi funkciók. Munkamegosztás a hét nagyvárosi régió között Magyarországon. - Falu-Város-Régió. 3-4. 35-43. o.

BBR (2004) Die Städte Europas. Heft 115 . Bundesamt für Bauwesen und Raumordnung, Bonn. 3-77. o.

Begg, I. (1999) Cities and Competitiveness. - Urban Studies. 5-6. 795-810. o.

Camagni, R. (2009) Territorial capital and regional development. - Capello, R.-Nijkamp, P. (eds.) Handbook of Regional Growth and Development Theories. Edwar Elgar Publ., Northampton. 118-132. o.

Enyedi Gy. (2003) Városi világ - városfejlödés a globalizáció korában. - Habilitációs Elöadások 4. Pécsi Tudományegyetem KTK Regionális Politika és Gazdaságtan Doktori Iskola, Pécs. 1-25. o.

ESPON (2004) The Role, specific situation and potentials of urban areas as nodes in a policentric development. European Spatial Planning Observation Network 1.1.1. http://www.espon.eu/mmp/ online/website/content/projects/259/648/file_1178/2.ir_1.1.1.pdf (Letöltés: 2005. 12. 20.)

ESPON (2005) Enlargement and polycentrism. European Spatial Planning Observation Network 1.1.3. http://www.espon.eu/mmp/online/website/content/projects/259/650/file_1190/full_revised_version_11 3.pdf. (Letöltés: 2006. 06. 23.)

ESPON (2006a) Mapping regional competitiveness and cohesion: European and global outlook on territorial diversities. ESPON Atlasz. http://www.espon.eu/mmp/online/website/content/publications/98/855/file_1500/ espon-briefing2.pdf (Letöltés: 2006. 10. 25.)

ESPON (2006b) Zoom in project. European Spatial Planning Observation Network 2.4.2. http://www.espon.eu/mmp/online/website/content/projects/243/388/file_4022/fr-2.4.2-full-r.pdf (Letöltés: 2007. 08. 23.)

ESPON (2007) ESDP Impact. European Spatial Planning Observation Network 2.3.1. http://www.espon.eu/mmp/online/website/content/projects/243/366/file_2183/fr-2.3.1-full_rev_Jan2007.pdf. (Letöltés: 2008. 04. 27.)

Európai Bizottság (2008a) Régiók 2020-ban. Értékelés az EU régiói elött álló jövöbeni kihivásokról. http://ec.europa.eu/regional_policy/sources/docoffic/working/regions2020/pdf/regions2020_en.pdf (Letöltés: 2009. 03. 30.)

Európai Bizottság (2008b) Ötödik elörehaladási jelentés. http://ec.europa.eu/legislation.../pr0001_en.htm (Letöltés: 2008. 10.20.)

Európai Bizottság (2008c) A European Economic Recovery Plan. COM(2008) 800

Európai Bizottság (2009a) An Agenda for a Reformed Cohesion Policy. Barca jelentés. http://ec.europa.eu/regional_policy/policy/future/pdf/report_barca_v0306.pdf (Letöltés: 2009. 05. 22.)

Európai Bizottság (2009b) Metropolitan regions in the EU. http://ec.europa.eu/regional_policy/ sources/docgener/focus/2009_01_metropolitan.pdf (Letöltés: 2009. 05. 25.)

Európai Bizottság (2009c) Hatodik helyzetjelentés a gazdasági és társadalmi kohézióról. COM 2009 (295). http://ec.europa.eu/regional_policy/sources/docoffic/official/reports/interim6/com_2009_295_hu.pdf (Letöltés: 2009. 05. 22.)

EUROSTAT (2009) Regionális évkönyv 2009. http://epp.eurostat.ec.europa.eu/cache/ITY_OFFPUB/KSHA-09-001/EN/KS-HA-09-001-EN.PDF (Letöltés: 2009. 08. 21.)

Faludi, A. (2009) Territorial Cohesion under the Looking Glass. Synthesis paper about the history of the concept and policy background to territorial cohesion. http://ec.europa.eu/regional_policy/ consultation/terco/pdf/lookingglass.pdf. (Letöltés: 2009. 05. 10.)

Friedmann, J. (1986) The world city hypothesis. - Development and Change. 17. 69-83. o. 
Friedmann, J. (1995) Where we stand: a decade of world city research. - Knox, P.-Taylor, T. (eds.) World Cities in a World-System. University Press, New York - Cambridge. 21-47. o.

Friedmann, J.-Wolf, G. (1982) World city formation: an agenda for research and action. - International Journal of Urban and Regional Research. 6. 309-344. o.

Krätke, S. (1995) Stadt, Raum, Ökonomie. Birkhäuser Verlag, Basel.

Lengyel I. (2003) Verseny és területi fejlödés. Térségek versenyképessége Magyarországon. JATE Press, Szeged. 3-433. o.

Lengyel I.-Rechnitzer, J. (2000) A városok versenyképességéröl. - Horváth Gy.-Rechnitzer J. (szerk.) Magyarország területi helyzete és folyamatai az ezredfordulón. MTA RKK, Pécs. 130-152. o.

Mehlbye, P. (2000) Global Integration Zones - Neighbouring Metropolitan Regions. - Metropolitan Clusters. Informationen zur Raumentwicklung. 11-12.755-762. o.

METREX (2005) Towards a Polycentric Metropolitan Europe. Interim Report on the PolyMETREX Plus Project. METREX The Network of European Metropolitan Regions and Areas, Glasgow. http://www.eurometrex.org/Docs/PolyMETREX/Interim/EN_PolyMETRExplus_interim_report.pdf (Letöltés: 2006. 11. 5.)

METREX (2007) PolyMETREX Plus közös kutatás az ESPONNAL. http://www.eurometrex.org/ Docs/Bulletins/METREX ESPON research needs note.pdf (Letöltés: 2008. 02. 01.)

OECD (2009) Investing for Growth: Building Innovative Regions. http://www.oecd.org/dataoecd/ 60/38/42531915.pdf (Letöltés: 2009. 05. 20.)

Rechnitzer J. (2006) A gazdaság térbeli sürüsödési pontjai. - Vértes A.-Viszt E. (szerk.) Tanulmányok Magyarország versenyképességéröl. Stratégiai kutatások - Magyarország 2015. Új Mandátum Könyvkiadó, Budapest. 231-254. o.

Rechnitzer J. (2007) Az európai regionális politika és városfejlódés. - Magyar Tudomány. 6. 692-708. o.

Schneider G. (2009) A közép-európai fövárosi régiók versenyképességének vizsgálata. Hogyan növelhetö a Közép-magyarországi régió versenyképessége. $\mathrm{PhD}$ értekezés.

Szente Z. (2007) Status of Capital Cities. Kézirat.

Szirmai V. (szerk.) (2009) A várostérségi versenyképesség társadalmi tényezói. Hogyan lehetnek a magyar nagyvárosok versenyképesebbek? Dialóg Campus Kiadó, Pécs-Budapest. 7-27. o.

Tavares, R. (2004) Contribution of macto-regions to the construction of peace: A framework for analysis. - Journal of International Relations and Development. 7. 24-47. o.

Taylor, P. (1995) World Cities and Territorial States: The rise and fall of their mutuality. -Knox, P.Taylor, P. (eds.) World Cities in a World-System. Cambridge University Press, New York-Cambridge. 48-62. o.

Taylor, P. (2002) Is there a Europe of cities? World cities and the limitations of geographical scale analysis. - McMaster, R.- Shepherd, E. (eds.) Scale and Geographic Inquiry. Blackwell, Oxford. 130-142. o. 